\title{
THE RELATIONSHIP BETWEEN SELF-CONFIDENCE AND LEARNING ENVIRONMENT AT HOME WITH STUDENTS MATHEMATICS LEARNING OUTCOMES IN SMP NEGERI 2 SANDEN
}

\author{
Nur Hidayatia ${ }^{a}$ Uswatun Khasanah ${ }^{\mathrm{b}}$ \\ Program Studi Pendidikan Matematika Universitas Ahmad Dahlan \\ Jalan Ring Road Selatan, Tamanan, Banguntapan, Bantul Yogyakarta \\ anurhidayati032@gmail.com, ${ }^{\text {buswatun.khasanah@pmat.uad.ac.id }}$
}

\begin{abstract}
Low self-confidence of students and the learning environment in the home students are still not conducive. This study aims to determine whether there is a positive and significant relationship between self-confidence and learning environment at home with student's mathematics learning outcomes of class VII SMP Negeri 2 Sanden Bantul second semester Academic Year 2015/2016. The population in this study were all students of class VIII SMP Negeri 2 Sanden Bantul in second semester Academic Year 2015/2016 consists of 8 classes. Taken as a class VII A of the class sample with a purposive sampling technique that is input from the school. The technique of collecting data are questioner and tests. The research instrument testing use validity testing, different potency testing, and reliability testing. The analysis of prerequisite testing includes a normality test, independent test, and linearity testing. The analysis of the data uses to hypothesis testing using correlation analysis of moment product and multiple linear regression analysis. The results of the analysis of variance with a significant level of $5 \%$ and $\mathrm{df}=25$ show that there is a positive and significant correlation between self-confidence and learning environment at home with mathematics learning outcomes with $F_{\text {count }}=3,742705182$ and $F_{\text {table }}=3,34$ so $F_{\text {count }} \geq F_{\text {table }}$. Multiple correlation coefficient $(\mathrm{R})=0,4800247482$ and the linear regression equation $\hat{Y}=-6,40017185+0,7301722041 X_{1}+0,4245148013 X_{2}$. Large relative contribution $X_{1}=54,551 \%$ and $X_{2}=45,449 \%$ and the effective contribution $X_{1}=12,569 \%$ and $X_{2}=$ $10,472 \%$.
\end{abstract}

Keywords: Self-Confidence, Learning Environment At Home, Learning Outcomes

\section{INTRODUCTION}

Education is very important in life, especially for the next generation to be able to compete with other developed countries, especially in the field of science. Education itself is a process of carrying out guidance, coaching or help with the aim that the child is capable enough to carry out his own life's tasks independently not too dependent on help from others. One way that can be done is by improving the quality of mathematics learning. Mathematics is one branch of science that is very useful in developing various fields of study and has the power to solve problems faced by humans. According to Suherman, E, et al. (2003: 55-56), School mathematics is mathematics taught in schools, namely mathematics taught in Elementary Education (Elementary and Junior High School) and Secondary Education (High School and Vocational School). The function of mathematics subjects is as a tool, mindset, and science.

2 factors influence student mathematics learning outcomes, namely internal factors, and external factors. According to Uno, Hamzah (2009: 139), mathematics learning outcomes are the result of activities from learning mathematics in the form of knowledge as a result of the treatment or learning done by students. In other words, the learning outcomes of mathematics are what students get from the learning process of mathematics. Self-confidence is one of the factors from within (internal) that affects the success of students in learning. According to John Fereira quoted by Chaerul Rochman and Heri Gunawan (2011: 77), To foster an attitude of confidence, students must have a good mentality, fitness, master learning materials, and must have a positive outlook on themselves and have good hopes about their future. Therefore, it is necessary to instill confidence in students so that the acquisition of mathematics learning outcomes can be maximized. The family environment is the first and foremost educational environment for students and includes external factors. According to Mariyana, Rita et al. (2010: 16-17), Environment can be interpreted as a place or atmosphere (condition) that can affect a person's growth and development. The factors of the learning environment at home according to 
Slameto (2010: 60 - 72) consist of 1) Family factors, which include (the way parents educate, relations between family members, home atmosphere, family economic conditions, understanding of parents, background culture). 2) Community factors, which include (student activities in society, mass media, associates, community life forms). Based on interviews with students of class VII of SMP Negeri 2 Sanden that some students do their homework at school because at home students prefer to play and things other than learning. The state of the learning environment at home is thought to cause low student learning outcomes.

\section{METHODS}

The research carried out by this researcher is quantitative research. This research was conducted at class VIII SMP Negeri 2 Sanden, Bantul Regency, with the research subjects being VII grade students of Even Semester 2015/2016 Academic Year. The learning process and data retrieval were carried out from May 13 to May 20, 2016. The population in this study was class VIII SMP Negeri 2 Sanden Bantul Regency 2015/2016 Academic Year consisting of 8 classes.

In this study, the sampling technique using the Purposive Sampling technique is based on input from the school. According to Sugiyono (2012: 124), the Purposive Sampling technique is a technique of determining samples with certain considerations. After consideration, the sample was obtained in class VII A consisting of 28 students as the study sample, while for the trial class was obtained class VII B which consisted of 28 students.

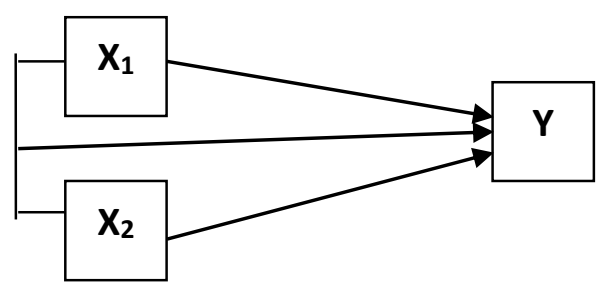

Information :

Picture 1. Research design

$\mathrm{X}_{1}$ : confidence

$\mathrm{X}_{2}$ : learning environment at home

$\mathrm{Y}$ : mathematics learning outcomes

A research instrument is a tool or facility used by researchers in describing data so that work is easier and the results are better in the sense of being faster, complete and systematic so that it is easier to process (Arikunto, Suharsimi 2010: 203).

The test statistic for testing is the hypothesis t-test, with the formula:

Information:

$$
t_{\text {stat }}=\frac{r \sqrt{n-2}}{\sqrt{1-r^{2}}}
$$

$\mathrm{R}$ : correlation coefficient

$\mathrm{N}$ : number of responses

(Sudjana, 2005:380)

The null hypothesis pair $\left(\mathrm{H}_{0}\right)$ and the match $\left(\mathrm{H}_{1}\right)$ for testing with the t-test hypotheses are:

a. First hypothesis

$H_{0,1}: \rho=0$

$H_{1,1}: \rho>0$

With :

$H_{0,1}$ : There is no positive and significant relationship between self-confidence and the results of mathematics learning in seventh-grade students in the even semester of class VIII SMP Negeri 2 Sanden Bantul Regency, 2015/2016 academic year. 
$H_{1,1}$ : There is a positive and significant relationship between self-confidence and the mathematics learning outcomes of class VII students in the even semester of class VIII SMP Negeri 2 Sanden Bantul Regency, 2015/2016 academic year.

b. Second hypothesis

$H_{0,2}: \rho=0$

$H_{1,2}: \rho>0$

With

$H_{0,2}$ : There is no positive and significant relationship between the home learning environment and the mathematics learning outcomes of class VII students in the even semester class VIII SMP Negeri 2 Sanden Bantul Regency in the 2015/2016 academic year.

$H_{1,2}$ : There is a positive and significant relationship between the home learning environment and the mathematics learning outcomes of class VII students in the even semester of class VIII SMP Negeri 2 Sanden Bantul Regency 2015/2016 academic year.

c. Third hypothesis

$H_{0,3}: \rho=0$

$H_{1,3}: \rho>0$

With

$H_{0,3}$ : There is no positive and significant relationship between self-confidence and the learning environment at home with the mathematics learning outcomes of class VII students in the even semester of class VIII SMP Negeri 2 Sanden Bantul Regency, 2015/2016 academic year.

$H_{1,3}$ : There is a positive and significant relationship between self-confidence and the learning environment at home with the mathematics learning outcomes of class VII students in the even semester of class VIII SMP Negeri 2 Sanden Bantul Regency, 2015/2016 academic year.

\section{RESULTS AND DISCUSSION}

\section{Relationship of Self-Confidence with Mathematics Learning Outcomes}

From the results of testing the hypothesis, it was found that there was a positive and significant relationship between self-confidence and the learning outcomes of mathematics. In other words the greater the confidence of students, the better the results of learning mathematics. In this study a simple correlation coefficient $(r)$ of equal to 0,4198783758 and determinant coefficients $\left(r^{2}\right)$ as big as 0,1762978505 as much as can be explained that $17,62978505 \%$ of learning outcomes are influenced by self-confidence while the rest is influenced by other factors. The variation in mathematics learning outcomes $(Y)$ is explained by self-confidence $\left(X_{1}\right)$ through a linear line $\hat{Y}=$ $3,688197078+1,024097220 X_{1}$, with a regression coefficient of 1,024097220 . This means that every increase of one unit $X_{1}$ result in 1,024097220 increase Y.

2. Relationship of Learning Environment at Home with Mathematics Learning Outcomes

From the results of testing the hypothesis, it was found that there was a positive and significant relationship between the learning environment at home and the learning outcomes of mathematics. In other words, the higher the level of the conducive learning environment at home, the higher the mathematics learning outcomes of these students. In this study, the simple correlation coefficient $(r)$ is 0,3997011094 and the determinant coefficient $\left(r^{2}\right)$ is equal to 0,1597609769 which can be explained that $15.97609769 \%$ of learning outcomes are influenced by the home learning environment while the rest is influenced by other factors. The variation in mathematics learning outcomes $(\mathrm{Y})$ is explained by the home learning environment $\left(\mathrm{X}_{2}\right)$ through a linear line $\hat{Y}=$ $26,89096267+0,647609692 X_{2}$, with a regression coefficient of 0.647609692 . This means that every increase of one unit $X_{3}$ results in a 0.647609692 increase in $Y$. 
3. Relationship between Self Confidence and Learning Environment at Home with Mathematics Learning Outcomes

The results of hypothesis testing prove that there is a positive and significant relationship at the 5\% level between self-confidence and the learning environment at home together with the learning outcomes of mathematics. This shows that the better the level of self-confidence and learning environment at home, the learning outcomes of mathematics will also be good. This study obtained a multiple correlation coefficient (r) of 0.4800247482 and a determinant coefficient $\left(r^{2}\right)$ of 0.230423759 which can be explained that $23.0423759 \%$ of learning outcomes are influenced by self-confidence and home learning environment while the rest is influenced by factors other. The variation in mathematics learning outcomes $(\mathrm{Y})$ explained by self-confidence $\left(\mathrm{X}_{1}\right)$ and home learning environment $\left(\mathrm{X}_{2}\right)$ through linear lines $\hat{Y}=-6,40017185+0,7301722041 X_{1}+$ $0,4245148013 X_{2}$. This means that every increase of one unit $\mathrm{X}_{1}$ results in a $0.7301722041 \mathrm{Y}$ increase and an increase of one unit $\mathrm{X}_{2}$ results in a $0.4245148013 \mathrm{Y}$ increase. Whereas the relative contribution of $X_{1}$ is $54.551 \%$ and $X_{2}$ is $45.449 \%$ and the effective contribution of $X_{1}$ is $12.569 \%$ and $\mathrm{X}_{2}$ is $10.472 \%$.

\section{CONCLUSION}

1. There is a positive and significant relationship between self-confidence and the mathematics learning outcomes of class VIII SMP Negeri 2 Sanden Bantul 2 semester 2015/2016. This is indicated by the t-test which is $t_{\text {count }}>t_{\text {table }}$ or 2,358984476>1,7056. A simple correlation coefficient $(r)$ between self-confidence and mathematics learning outcomes is 0.4198783758 with a linear regression equation $\hat{Y}=3,688197078+1,024097220 X_{1}$.

2. There is a positive and significant relationship between the learning environment at home and the mathematics learning outcomes of class VIII SMP Negeri 2 Sanden Bantul in the second semester of the academic year 2015/2016. This is indicated by the t-test which is $t_{\text {count }}>t_{\text {table }}$ or $2,223415372>1,7056$. A simple correlation coefficient $(r)$ between the learning environment at home and mathematics learning outcomes is 0,3997011094 with a linear regression equation $\hat{Y}=$ $26,89096267+0,647609692 X_{2}$.

3. There is a positive and significant relationship between self-confidence and the learning environment at home with the mathematics learning outcomes of class VIII SMP Negeri 2 Sanden Bantul in the even semester 2015/2016 academic year. This is indicated by the - F test which is $F_{\text {count }}>F_{\text {table }}$ or $3,742705182>3,34$. Multiple correlation coefficient $(R)$ between selfconfidence and learning environment at home with mathematics learning outcomes of 0.4800247482 and $\left(R^{2}\right)$ of 0.230423759 with multiple linear regression equations $\widehat{Y}=-6,40017185$ $+0,7301722041 X_{1}+0,4245148013 X_{2}$. The relative contribution of $X_{1}$ is $54.551 \%$ and the relative contribution of $X_{2}$ is $45.449 \%$ and the effective contribution of $X_{1}$ is $12.569 \%$ and the effective contribution of $\mathrm{X}_{2}$ is $10.472 \%$.

\section{REFERENCES}

Arikunto, Suharsimi. 2010. Prosedur Penelitian Suatu Pendekatan Praktik. Jakarta: Rineka Cipta.

Chaerul Rochman dan Heri Gunawan. 2011. Pengembangan Kompetensi Kepribadian Guru. Bandung: Nuansa Cendekia.

Mariyana, Rita dkk. 2010. PengelolaanLingkungan Belajar. Jakarta: Kencana Prenada Media Group.

Slameto. 2010. Belajar dan Faktor-Faktor Yang Mempengaruhinya. Jakarta: Rineka Cipta.

Sudjana. 2005. Metoda StatistikaBandung: Tarsito.

Sugiyono. 2012. Metode Penelitian Pendidikan Pendekatan Kuantitatif, kualitatif, dan R\&D. Bandung: Alfabeta.

Suherman, E,dkk. 2003. StrategiPembelajaranMatematikaKontemporer. Jakarta: UniversitasPendidikan Indonesia.

Uno, Hamzah. 2009. ModelPembelajaran. Jakarta: Bumi Aksara. 